\title{
Research on Service Quality of Telecom Corporation Based on PZB Model
}

\author{
Hung-Chi Hsu ${ }^{1}$, Hui-Lin Hsu ${ }^{1}$, Yue-Hua Mo ${ }^{1}$ and Mei-Zhen $\mathrm{He}^{2, *}$ \\ ${ }^{1}$ School of Business Administration, Baise University, Baise, Guangxi, 533000 China. \\ ${ }^{2}$ School of Business Administration, Guangxi University of Finance and Economics, Guangxi, 53003, China
}

"Corresponding author. Email: 2018210021@gxufe.edu.com

\begin{abstract}
With the rapid development of information technology, wireless mobile communication services have become increasingly fierce. This study uses telecommunications companies as a research case to explore the gaps between service quality and customer expectations. The research object is the current customers of the telecommunications company. This study uses questionnaires as a research tool to collect data, analysis and obtain the results. The measurement indicators of service quality in the questionnaire are based on the SERVQUAL scale in the PZB model. It is an evaluation system proposed in the service industry based on the theory of Total Quality Management (TQM). In this study, combined with the services characteristics of telecommunications companies, the SERVQUAL scale was used to design a questionnaire on the service quality of telecommunications companies. Through the collected questionnaire data, it is found that the company's service quality has the following problems, including less personalized service provision, higher error rate of staff service, poor business ability of staff, lack of professional knowledge of staff, and inability to handle customer complaints in a timely manner, etc. Finally, in response to the service quality problems found in this study, based on the 5gap model, suggestions for improvement and adjustment of service quality are proposed.
\end{abstract}

Keywords: service quality; PZB model; 5gap model; expected service

\section{INTRODUCTION}

As the development of the telecommunications industry enters maturity, marketing has walked towards a customercentric, service-oriented era, which also represents that companies must pay more attention to service quality. At present, 4G mobile internet has been trendy. The $5 \mathrm{G}$ has not met mature development into people's lives, and companies must face the threat of market maturity and product homogenesis whether service product or customer service. The cores for both services are the service quality. The quality of service also determines the level of the product added-value, so use the technology to improvement of service quality to meet customers' needs, increase customer satisfaction and identity to enhance the competitiveness is the only way for companies to survive. Due to the intangibility of service quality, it is impossible to measure the objective standards like a tangible product, so it is necessary to evaluate the subjective feeling of customers through scale. The primary significance of this study is to explore the status quo of the service quality of telecommunications, using the SERVQUAL theory to formulate an evaluation scale by telecom's quality characteristics. Moreover, study the service quality problem through customer feedback and questionnaire data, analyze the cause of the problem, and propose corresponding improvement strategies, eliminate the gaps between actual quality of service and customer expectations, through improving the service quality to achieve customer perceived service and winning in a competitive market.

\section{LITERATURE}

"Services" are invisible and unique products with no fixed standard mode. Measuring the quality of service is a challenge because the customer's satisfaction is affected by many invisible factors and consumer psychology qualities. In other words, the quality of service is measured depending on the subjective feeling of customers. Churchill and Suprenant (1982) believe that service quality is the satisfaction of consumers for services, while service satisfaction depends on the gap between actual service and the original expectations [2]. Parasuraman et al. considered service quality should be defined as the consciousness level of gap that actual service and it providing services in advance. When the gap between the two is large, the service quality is low, and vice versa, the service quality is high. [5].

This study takes a SERVQUAL scale as a tool for measuring service quality. The SERVQUAL scale is evolved from the ten attributes of the "Service Quality Concept Model" (PZB Model) proposed in 1985 by American Scholar Parasuraman, Zeithaml and Leonard L. Berry [5]. They selected four industries: banks, credit card 
companies, securities brokers, and repair shops to conduct an exploratory study. After focus group interviews with customers, they developed ten aspects of service quality. In 1988, three scholars further used the electrical maintenance industry, banks, long-distance telephone companies, securities brokers, and credit card companies as research objects and refined ten aspects into five components called the "SERVQUAL" [6]. The customer can measure the quality of service through the gap between the five components. The company measures the gap between the desired service and the perceived service of consumers as the basis for feedback and improvement.

The SERVQUAL model is widely used in the service industry to understand the service needs and perception of target customers and provide strategies for companies to manage and measure service quality. Bolton and Drew (1991) expand Zeithaml's (1988) model, with telephone users as an empirical object, proposing multi-stage models of service quality and service value [1]. In this model, the customer's service evaluation process is divided into three interrelated stages: service exercise, service quality, and service value. Subsequently, many scholars continue to improve and develop this model, just like O'Connor Shewchuk Carney pointed out that SERVQUAL is currently the most widely used service quality measurement model in academia [2-4].

\section{RESEARCH METHODOLOGY AND DESIGN}

To achieve research purposes, this study adopts the PZB model and the SERVQUAL scale, and uses scientific quantitative analysis methods to analyze the factors affecting service quality according to the service characteristics of telecom company. The SERVQUAL divides the quality of the service into five dimensions: Tangibles, Reliability, Responsiveness, Assurances, Empathy; each dimension is subdivided into several issues. Through questionnaires, customers are allowed to evaluate and score the expected value, actual feeling value and minimum acceptable value for each question. Then calculate the service quality scores. The model is based on the gap theory, that is, the difference between the customer's expectation of the service quality and the service received by the customer from the service organization. The five measurement dimensions are as followings:

(1)Tangibles includes a list of practical facilities, equipment, and service personnel.

(2)Reliability refers to the ability to perform service commitments in reliably.

(3)Responsiveness refers to the willingness to help customers and quickly improve service levels.

(4)Assurance refers to the knowledge, etiquette, and the ability to express confidence and credibility.

(5)Empathy refers to the concern and provides personalized services for customers.
The content of the service quality questionnaire in this study is mainly modified based on the revised SERVQUAL questionnaire by Parasuraman et al. in 1991 [7]. After preliminary prediction, the feasibility of the questionnaire content is confirmed, and then the questionnaire is formally distributed. Therefore, the content validity of the questionnaire has considerable visibility.

The questionnaire design is mainly divided into two parts of the content; the first part is mainly for the demographic characteristics of the survey object including gender, age, consumption, etc.; the second part is mainly designed for the SERVQUAL scale, Contains five dimensions of 21questions. The Li Kete five-points scale is used, which including "far lower the expected value", "slightly lower than the expected value", "consistent with the expected value", "Slightly higher than the expected value" and "far higher than the expected value". The object of the questionnaire survey is current customers, and the questionnaire is distributed and collected to customers at many business locations by means of on-site distribution. In order to confirm the appropriateness of the questionnaire, first of all, the questionnaire pre-test was carried out, and 110 predictive questionnaires were returned, of which 0 were invalid. The effective recovery rate of the pre-test questionnaire was $100 \%$. Then, 411 formal questionnaires were distributed and recovered, 20 invalid questionnaires were detected, and invalid samples were eliminated with SPSSAU software. There were 391 valid questionnaires, and the effective recovery rate was $95.13 \%$. The data collected from this formal questionnaire can fully support the research conclusions of the thesis

The pre-test questionnaire is mainly used to understand the appropriateness of the questionnaire, confirm that the contents of the questionnaire can reflect the aspect of the investigation, and ensure the reliability and validity of the questionnaire. In this study, Cronbach's $\alpha$ coefficient as a measure of reliability, the five facets alpha coefficients from pre-test survey are $0.937,0.938,0.915,0.931,0.953$, KMO values are all greater than 0.8 . Formal questionnaire has 21 questions, total $\alpha$ coefficient was 0.948 , CITC values were greater than 0.55 . These indicators strongly show that the questionnaire is stable enough to support the conclusions of this research.

\section{DATA ANALYSIS AND RESULT}

The questionnaire survey data is collected, the percentage, average number, standard deviation, differential analysis, and other statistical analysis have been organized, and the results are presented to obtain research conclusions and suggestions. The results of the study and feedback analysis are as follows.

\subsection{Descriptive Statistical Analysis}

The demographic characteristics of the survey subjects include gender, age, customer type, and consumption 
amount. The survey results are as follows: the proportion of men and women is $45.01 \%$ and $54.99 \%$ respectively. In the age survey data, it is found that the 26-35 years old accounted for the highest proportion of $33.76 \%$, the $36-45$ years old accounted for $29.92 \%$, the $16-25$ years old accounted for $19.44 \%$, and those over 46 years old amounted for the lowest $16.88 \%$. Above data shows this survey objects are mainly concentrated in young people and middle-aged people under 46. The proportion of individual customers is much larger than that of corporate customers, $79.54 \%$ and $20.46 \%$ respectively. Among the survey respondents, the highest proportion of monthly average consumption of RMB100-199 yuan is $31.46 \%$, followed by RMB 200-299 yuan is $25.06 \%$, and those below RMB 99 yuan is $21.48 \%$, the lowest proportions of RMB 300-399 yuan and more than RMB 400 yuan are $11.25 \%$ and $10.74 \%$ respectively.

\subsection{Questionnaire Statistical Analysis}

The research results from five-dimensional analysis are reported as follows.

\subsubsection{Tangible statistical analysis}

As can be seen from the table $1,53 \%$ of the clients in $\mathrm{T} 1$ believe that technical equipment and technical environments can meet their needs, but $46 \%$ disagreed. Nearly $53 \%$ of customers in T2 believe that the management standardization, and $46 \%$ of customers disagree. $56 \%$ of customers in $\mathrm{T} 3$ believe that employees are dressed neatly. T4 data shows that nearly $53 \%$ of customers find that service activities are attractive, but $46 \%$ are still dissatisfied.

\subsubsection{Reliability statistical analysis}

The data from T5 question of table 2 shows that $50 \%$ of customers believe that employees do not provide adequate and satisfactory services to customers within the prescribed business hours. In T6, 52\% of customers think that there is a high error rate in solving customer problems. In T7, there are more than $49 \%$ of customers feel that employees cannot skillfully use the business knowledge in solving problems and complaints. T8 data shows that only less than $48 \%$ of customers feel that corporate reputation and service quality are constantly improving. Reliability research results show that more than half of customers are dissatisfied with the four indicators from $\mathrm{T} 5$ to $\mathrm{T} 8$.

\subsubsection{Responsiveness statistical analysis}

From data of T9, 53\% of customer approval employees can provide respective services promptly. In the T10 data, 55\% of customers feel that employees have failed to resolve the questions, needs and complaints raised by customers on the spot, and they have not promised a time limit for solving problems. According to T11 data, it is found that more than $53 \%$ of customers believe that employees are not customercentric and not focusing on customer interests. The data of T12 shows that more than $52 \%$ of customers feel that employees cannot correct and resolve errors in the service process in time. In summary, customers are dissatisfied with the service quality in terms of responsiveness.

Table 1. Tangible Statistical Analysis(\%)

\begin{tabular}{llllllll}
\hline Item & $\begin{array}{l}\text { Far lower } \\
\text { than the } \\
\text { expected } \\
\text { value (A) }\end{array}$ & $\begin{array}{l}\text { Slightly } \\
\text { lower than } \\
\text { the expected } \\
\text { value(B) }\end{array}$ & $\begin{array}{l}\text { Consistent } \\
\text { with the } \\
\text { expected } \\
\text { value (C) }\end{array}$ & $\begin{array}{l}\text { Slightly } \\
\text { higher than } \\
\text { the expected } \\
\text { value (D) }\end{array}$ & $\begin{array}{l}\text { Far higher } \\
\text { than the } \\
\text { expected } \\
\text { value(E) }\end{array}$ & $\begin{array}{l}\text { Lower than } \\
\text { Expected } \\
\text { value } \\
\text { (F=A+B) }\end{array}$ & $\begin{array}{l}\text { Equity or } \\
\text { higher than } \\
\text { the expected } \\
\text { value } \\
\text { (G=C+D+E) }\end{array}$ \\
\hline T1 & 25.83 & 20.46 & 24.55 & 16.11 & 13.04 & 46.29 & 53.70 \\
T2 & 26.85 & 19.95 & 20.20 & 16.62 & 16.37 & 46.80 & 53.19 \\
T3 & 21.48 & 22.51 & 19.44 & 20.46 & 16.11 & 43.99 & 56.01 \\
T4 & 23.27 & 24.04 & 19.44 & 20.20 & 13.04 & 47.31 & 52.68 \\
\hline
\end{tabular}

Table 2. Reliability Statistical Analysis(\%)

\begin{tabular}{llllllll}
\hline Item & $\begin{array}{l}\text { Far lower } \\
\text { than the } \\
\text { expected } \\
\text { value (A) }\end{array}$ & $\begin{array}{l}\text { Slightly } \\
\text { lower than } \\
\text { the expected } \\
\text { value(B) }\end{array}$ & $\begin{array}{l}\text { Consistent } \\
\text { with the } \\
\text { expected } \\
\text { value (C) }\end{array}$ & $\begin{array}{l}\text { Slightly } \\
\text { higher than } \\
\text { the expected } \\
\text { value (D) }\end{array}$ & $\begin{array}{l}\text { Far higher } \\
\text { than the } \\
\text { expected } \\
\text { value(E) }\end{array}$ & $\begin{array}{l}\text { Lower than } \\
\text { Expected } \\
\text { value } \\
\text { (F=A+B) }\end{array}$ & $\begin{array}{l}\text { Equity or } \\
\text { higher than } \\
\text { the expected } \\
\text { value } \\
\text { (G=C+D+E) }\end{array}$ \\
\hline T5 & 28.90 & 21.23 & 17.90 & 18.16 & 13.81 & 50.13 & 49.87 \\
T6 & 28.64 & 23.02 & 18.93 & 17.90 & 11.51 & 51.66 & 48.34 \\
T7 & 24.81 & 24.55 & 19.95 & 15.09 & 15.60 & 49.36 & 50.64 \\
T8 & 23.27 & 28.90 & 17.90 & 14.83 & 15.09 & 52.17 & 47.82 \\
\hline
\end{tabular}


Table 3. Responsiveness Statistical Analysis (\%)

\begin{tabular}{llllllll}
\hline & $\begin{array}{l}\text { Far lower } \\
\text { than the } \\
\text { expected } \\
\text { value (A) }\end{array}$ & $\begin{array}{l}\text { Slightly } \\
\text { lower than } \\
\text { the expected } \\
\text { value (B) }\end{array}$ & $\begin{array}{l}\text { Consistent } \\
\text { with the } \\
\text { expected } \\
\text { value (C) }\end{array}$ & $\begin{array}{l}\text { Slightly } \\
\text { higher than } \\
\text { the expected } \\
\text { value (D) }\end{array}$ & $\begin{array}{l}\text { Far higher } \\
\text { than the } \\
\text { expected } \\
\text { value (E) }\end{array}$ & $\begin{array}{l}\text { Lower than Equity or } \\
\text { Expected } \\
\text { value } \\
\text { (F=A+B) }\end{array}$ & $\begin{array}{l}\text { Eigher than } \\
\text { the expected } \\
\text { value } \\
\text { (G=C+D+E) }\end{array}$ \\
\hline $\mathrm{T} 9$ & 20.97 & 25.83 & 20.46 & 16.11 & 16.62 & 46.80 & 53.19 \\
$\mathrm{~T} 10$ & 23.27 & 31.46 & 16.62 & 16.11 & 12.53 & 54.73 & 45.26 \\
$\mathrm{~T} 11$ & 26.34 & 27.11 & 18.16 & 13.81 & 14.58 & 53.45 & 46.55 \\
$\mathrm{~T} 12$ & 20.20 & 32.23 & 18.67 & 13.04 & 15.86 & 52.43 & 47.57 \\
\hline
\end{tabular}

Table 4. Assurance Statistical Analysis (\%)

\begin{tabular}{llclllll}
\hline Item & $\begin{array}{l}\text { Far lower } \\
\text { than the } \\
\text { expected } \\
\text { value (A) }\end{array}$ & $\begin{array}{l}\text { Slightly } \\
\text { lower than } \\
\text { the expected } \\
\text { value (B) }\end{array}$ & $\begin{array}{l}\text { Consistent } \\
\text { with the } \\
\text { expected } \\
\text { value (C) }\end{array}$ & $\begin{array}{l}\text { Slightly } \\
\text { higher than } \\
\text { the expected } \\
\text { value (D) }\end{array}$ & $\begin{array}{l}\text { Far higher } \\
\text { than the } \\
\text { expected } \\
\text { value (E) }\end{array}$ & $\begin{array}{l}\text { Lower than } \\
\text { Expected } \\
\text { value } \\
\text { (F=A+B) }\end{array}$ & $\begin{array}{l}\text { Equity or } \\
\text { higher than } \\
\text { the expected } \\
\text { value } \\
\text { (G=C+D+E) }\end{array}$ \\
\hline T13 & 22.51 & 30.95 & 17.90 & 15.86 & 12.79 & 53.45 & 46.55 \\
T14 & 19.95 & 33.50 & 18.67 & 14.07 & 13.81 & 53.45 & 46.55 \\
T15 & 19.19 & 28.90 & 22.25 & 16.62 & 13.04 & 48.09 & 51.91 \\
T16 & 28,64 & 25.32 & 15.86 & 17.65 & 12.53 & 53.96 & 46.04 \\
\hline
\end{tabular}

Table 5. Empathy Statistical Analysis (\%)

\begin{tabular}{llllllll}
\hline Item & $\begin{array}{l}\text { Far lower } \\
\text { than the } \\
\text { expected } \\
\text { value (A) }\end{array}$ & $\begin{array}{l}\text { Slightly } \\
\text { lower than } \\
\text { the expected } \\
\text { value (B) }\end{array}$ & $\begin{array}{l}\text { Consistent } \\
\text { with the } \\
\text { expected } \\
\text { value (C) }\end{array}$ & $\begin{array}{l}\text { Slightly } \\
\text { higher than } \\
\text { the expected } \\
\text { value (D) }\end{array}$ & $\begin{array}{l}\text { Far higher } \\
\text { than the } \\
\text { expected } \\
\text { value (E) }\end{array}$ & $\begin{array}{l}\text { Lower than } \\
\text { Expected } \\
\text { value } \\
\text { (F=A+B) }\end{array}$ & $\begin{array}{l}\text { Equity or } \\
\text { higher than } \\
\text { the expected } \\
\text { value } \\
\text { (G=C+D+E) }\end{array}$ \\
\hline T17 & 24.55 & 28.90 & 16.11 & 15.61 & 14.83 & 53.45 & 46.55 \\
T18 & 21.98 & 28.64 & 21.74 & 15.35 & 12.28 & 50.63 & 49.37 \\
T19 & 24.55 & 26.09 & 19.18 & 17.90 & 12.28 & 50.64 & 49.36 \\
T20 & 29.15 & 27.37 & 17.39 & 13.30 & 12.79 & 56.52 & 43.48 \\
T21 & 25.83 & 27.37 & 13.81 & 15.60 & 17.39 & 53.20 & 56.29 \\
\hline
\end{tabular}

\subsubsection{Assurance statistical analysis}

In table4, T13 data shows that there are $53 \%$ of customers feel that employees do not feel trustworthy. T14 data indicates that $53 \%$ of customers feel that employees' service attitudes lack warmth and politeness. T15 shows that $51.91 \%$ of customers are satisfied with employees' knowledge, skills and ability to solve problems quickly. In the T16 data, $54 \%$ of customers who believe that the company's human resources have not received sufficient, perfect training. In summary, it can be seen that in terms of the dimension of assurance service quality, most customers have a disapproval attitude.

\subsubsection{Empathy statistical analysis}

From T17 data in table5, there are $53.45 \%$ of customers believe that the company did not provide flexible and personalized services. Among the T19, half of the customers believe that employees cannot understand the actual needs of customers and have difficulty communicating with customers. In the T20 data, more than $56 \%$ of customers believe that employees cannot understand and make timely adjustments in face of customer emergencies. The T21 data show that $53.2 \%$ of customers believe that the company's unique service channels, emergency service channels, or service guidelines cannot meet customer needs. Overall, the above results show that the quality of services provided by the company in terms of empathy are far below the expectations of customers.

\subsection{Analysis of Service Quality Weight}

Combining the above statistical results, the factor analysis tool in SPSSAU is used to calculate the weight of each dimension, and then the weight coefficient is obtained through the weight calculation formula, as shown in Table 6. The weights of the four dimensions of empathy, reliability, responsiveness, and assurance are accounted for $20.84 \%, 20.80 \%, 20.75 \%$, and $20.09 \%$, which are very 
close for each dimension, indicating that customers attach almost equal importance to the service quality of these four dimensions. The weight of the tangible dimension is only $17.52 \%$, which shows that the service quality of the tangible dimension has received relatively low attention from customers.
Based on the above statistical analysis, this study found that this company's service quality in the four dimensions of empathy, reliability, responsiveness, and assurance did not meet customer expectations. That is to say, the service quality provided by this company did not achieve recognition from its customers.

Table 6. Analysis of Service Quality Weight

\begin{tabular}{|c|c|c|c|c|}
\hline Dimensions & $\begin{array}{c}\text { Dimension } \\
\text { weight }\end{array}$ & Item & Weight coefficient (before weighted) & Weight coefficient (after weighted) \\
\hline \multirow{4}{*}{ Tangible } & \multirow{4}{*}{$17.52 \%$} & $\mathrm{~T} 1$ & $23.87 \%$ & $4.18 \%$ \\
\hline & & $\mathrm{T} 2$ & $25.39 \%$ & $4.45 \%$ \\
\hline & & T3 & $25.74 \%$ & $4.51 \%$ \\
\hline & & $\mathrm{T} 4$ & $25.00 \%$ & $4.38 \%$ \\
\hline \multirow{4}{*}{ Reliability } & \multirow{4}{*}{$20.80 \%$} & T5 & $25.60 \%$ & $5.32 \%$ \\
\hline & & T6 & $25.06 \%$ & $5.21 \%$ \\
\hline & & $\mathrm{T} 7$ & $24.69 \%$ & $5.14 \%$ \\
\hline & & T8 & $24.64 \%$ & $5.13 \%$ \\
\hline \multirow{4}{*}{ Responsiveness } & \multirow{4}{*}{$20.75 \%$} & T9 & $24.02 \%$ & $4.98 \%$ \\
\hline & & $\mathrm{T} 10$ & $25.55 \%$ & $5.30 \%$ \\
\hline & & T11 & $25.45 \%$ & $5.28 \%$ \\
\hline & & $\mathrm{T} 12$ & $24.98 \%$ & $5.18 \%$ \\
\hline \multirow{4}{*}{ Assurance } & \multirow{4}{*}{$20.09 \%$} & T13 & $24.83 \%$ & $4.99 \%$ \\
\hline & & $\mathrm{T} 14$ & $24.53 \%$ & $4.93 \%$ \\
\hline & & $\mathrm{T} 15$ & $24.67 \%$ & $4.96 \%$ \\
\hline & & T16 & $25.97 \%$ & $5.22 \%$ \\
\hline \multirow{5}{*}{ Empathy } & \multirow{5}{*}{$20.84 \%$} & T17 & $19.79 \%$ & $4.12 \%$ \\
\hline & & T18 & $20.06 \%$ & $4.18 \%$ \\
\hline & & T19 & $20.42 \%$ & $4.26 \%$ \\
\hline & & T20 & $18.89 \%$ & $3.94 \%$ \\
\hline & & $\mathrm{T} 21$ & $20.85 \%$ & $4.35 \%$ \\
\hline
\end{tabular}

\section{RECOMMENDATIONS FOR THE APPLICATION OF THE PZB MODEL AND 5GAP MODEL}

Companies can use the 5gap model to understand customer satisfaction. The 5 gap model helps companies identify the gap between perceived services and expected services. According to the above study result, this study uses the 5 gap model, as shown in figure 1 , to identify the 5 gaps in the service delivery process, and proposes the following recommendations.

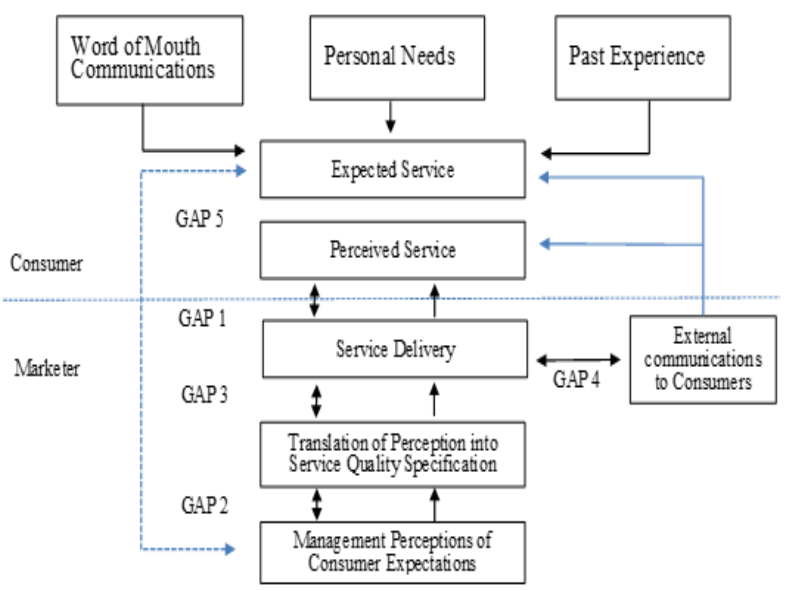

Figure 1. 5gap model of service quality 


\subsection{GAP1: Managers Perception Gap}

The gap between customer expectations and the company's products and services.

Suggestions:

(1) Strengthen market research, regularly conduct customer satisfaction surveys, and improve it according to customer response.

(2) Strengthen the problems and customer concerns of employees and follow up in time.

(3) Promptly, the mistakes generated during the remedial process have expressed apologies to ensure customer satisfaction

\subsection{GAP2: Quality Standard Gap}

The gap between customer expectations and the service quality specifications provided by the company.

Suggestions:

(1) Develop a standard of quality standard, design, and improve the service architecture.

(2) Develop effective performance assessment criteria to improve the enthusiasm of employees.

(3) Design an integral service standard, show a good attitude and enthusiasm for service.

(4) Integrate online and offline services.

\subsection{GAP3: Service Trading Gap}

The gap between the service quality specifications and the actual services provided by company.

Suggestions:

(1) Establish a service concept that is customer-centered and values customer interests.

(2) Strengthen interaction with customers and improve customer experience.

\subsection{GAP4: Marketing Communication Gap}

The gap between the actual services provided and the promotional services.

Suggestions:

(1) Strengthen the management of customer expectations, so as to truly understand the actual needs of customers.

(2) Strengthen effective customer communication, not exaggerated or explained arbitrarily.

(3) The commitment to the customer must be honored, and a sense of trust is established.

\subsection{GAP5: Service Experience Gap}

The gap between customer expectations and service experiences actually.

Suggestions:
(1) Strengthen the management of customer feedback, and timely adjust and modify the service to customers.

(2) Implement dynamic training of service personnel to ensure timely response to customer needs and improve customer consumption experience.

\section{CONCLUSION}

The object of organizing services is person, and the goal is to satisfy customer's material and spiritual needs. Through the contact between enterprises and customers, the quality of the servers determines customer satisfaction. In addition to implementing the above four gaps, companies must dynamically adjust the service based on the customer's feedback and adjust the tactics in a timely change of the external environment.

\section{REFERENCES}

[1] Bolton R. N. and J. H. Drew, "A multistage model of consumers' assessments of service quality and value," Journal of Consumer Research, vol. 17, pp. 375-384, 1991

[2] Churchill, G. A., and Surprenant, C., “An investigation into the determinants of customer satisfaction," Journal of Marketing Research, vol. 19(24), pp. 491-504, 1982.

[3] Brown TJ, Churchill GC, Peter JP., "Research note: improving the measurement of service quality," Journal of Retailing, vol. 69, pp. 127-39, 1993.

[4] O'Connor SJ, Shewchuk RM, Carney LW., "The great gap. Physicians' perceptions of patient service quality expectations fall short of reality," Journal of Health Care Mark, vol. 14, pp.32-9, 1994.

[5] Parasuraman, A., Zeithaml, V. A. and Berry, L. L., "A conceptual model of service quality and its implication for future research," Journal of Marketing, vol. 49, pp. 41-50, 1985.

[6] Parasuraman, A., Zeithaml, V. A. \& Berry, L. L., "SERVQUAL: A multiple-item scale for measuring consumer perceptions of service quality," Journal of Retailing, vol. 64, pp. 12- 41,1988.

[7] Zeithaml, V. A. \& Berry, L. L., "Refinement and Reassessment of the SERVQUAL Scale," Journal of Retailing, vol. 67(4), pp. 420-450, 1991. 